\title{
The Equilibrium Phase Formation and Thermodynamic Properties of Functional Tellurides in the Ag-Fe-Ge-Te System
}

\author{
Mykola Moroz ${ }^{1,2, *(\mathbb{D}}$, Fiseha Tesfaye ${ }^{3, *(\mathbb{C})}$, Pavlo Demchenko ${ }^{4}$, Myroslava Prokhorenko ${ }^{5}$, Nataliya Yarema ${ }^{5}$, \\ Daniel Lindberg ${ }^{6}{ }^{\infty}$, Oleksandr Reshetnyak ${ }^{2}$ and Leena Hupa ${ }^{3}$ \\ 1 Department of Chemistry and Physics, National University of Water and Environmental Engineering, \\ 33028 Rivne, Ukraine \\ 2 Department of Physical and Colloid Chemistry, Ivan Franko National University of Lviv, 79005 Lviv, Ukraine; \\ oleksandr.reshetnyak@lnu.edu.ua \\ 3 Johan Gadolin Process Chemistry Centre, Åbo Akademi University, 20500 Turku, Finland; leena.hupa@abo.fi \\ 4 Department of Inorganic Chemistry, Ivan Franko National University of Lviv, 79005 Lviv, Ukraine; \\ pavlo.demchenko@lnu.edu.ua \\ 5 Department of Cartography and Geospatial Modeling, Lviv Polytechnic National University, \\ 79013 Lviv, Ukraine; myroslava.v.prokhorenko@lpnu.ua (M.P.); nataliia.p.yarema@lpnu.ua (N.Y.) \\ 6 Department of Chemical and Metallurgical Engineering, Aalto University, Kemistintie 1, \\ 02150 Espoo, Finland; daniel.k.lindberg@aalto.fi \\ * Correspondence: m.v.moroz@nuwm.edu.ua (M.M.); fiseha.tesfaye@abo.fi (F.T.)
}

check for

updates

Citation: Moroz, M.; Tesfaye, F.; Demchenko, P.; Prokhorenko, M.; Yarema, N.; Lindberg, D.; Reshetnyak, O.; Hupa, L. The Equilibrium Phase Formation and Thermodynamic Properties of Functional Tellurides in the Ag-Fe-Ge-Te System. Energies 2021, 14, 1314. https://doi.org/ $10.3390 /$ en14051314

Academic Editor: Lyes Bennamoun

Received: 31 December 2020

Accepted: 25 February 2021

Published: 28 February 2021

Publisher's Note: MDPI stays neutral with regard to jurisdictional claims in published maps and institutional affiliations.

Copyright: (C) 2021 by the authors. Licensee MDPI, Basel, Switzerland. This article is an open access article distributed under the terms and conditions of the Creative Commons Attribution (CC BY) license (https:// creativecommons.org/licenses/by/ $4.0 /)$

\begin{abstract}
Equilibrium phase formations below $600 \mathrm{~K}$ in the parts $\mathrm{Ag}_{2} \mathrm{Te}-\mathrm{FeTe}_{2}-\mathrm{F}_{1.12} \mathrm{Te}-\mathrm{Ag}_{2} \mathrm{Te}$ and $\mathrm{Ag}_{8} \mathrm{GeTe}_{6}-\mathrm{GeTe}_{-} \mathrm{FeTe}_{2}-\mathrm{AgFeTe}{ }_{2}-\mathrm{Ag}_{8} \mathrm{GeTe}_{6}$ of the $\mathrm{Fe}-\mathrm{Ag}-\mathrm{Ge}-\mathrm{Te}$ system were established by the electromotive force (EMF) method. The positions of 3- and 4-phase regions relative to the composition of silver were applied to express the potential reactions involving the $\mathrm{AgFeTe}_{2}, \mathrm{Ag}_{2} \mathrm{FeTe}_{2}$, and $\mathrm{Ag}_{2} \mathrm{FeGeTe}_{4}$ compounds. The equilibrium synthesis of the set of phases was performed inside positive electrodes (PE) of the electrochemical cells: (-)Graphite $\|\mathrm{LE}\|$ Fast $\mathrm{Ag}^{+}$conducting solidelectrolyte $\left\|\mathrm{R}\left[\mathrm{Ag}^{+}\right]\right\| \mathrm{PE} \|$ Graphite(+), where LE is the left (negative) electrode, and $\mathrm{R}\left[\mathrm{Ag}^{+}\right]$is the buffer region for the diffusion of $\mathrm{Ag}^{+}$ions into the PE. From the observed results, thermodynamic quantities of $\mathrm{AgFeTe}_{2}, \mathrm{Ag}_{2} \mathrm{FeTe}_{2}$, and $\mathrm{Ag}_{2} \mathrm{FeGeTe}_{4}$ were experimentally determined for the first time. The reliability of the division of the $\mathrm{Ag}_{2} \mathrm{Te}-\mathrm{FeTe}_{2}-\mathrm{F}_{1.12} \mathrm{Te}-\mathrm{Ag}_{2} \mathrm{Te}$ and $\mathrm{Ag}_{8} \mathrm{GeTe}_{6}-\mathrm{GeTe}_{-} \mathrm{FeTe}_{2}-$ $\mathrm{AgFeTe}_{2}-\mathrm{Ag}_{8} \mathrm{GeTe}_{6}$ phase regions was confirmed by the calculated thermodynamic quantities of $\mathrm{AgFeTe}_{2}, \mathrm{Ag}_{2} \mathrm{FeTe}_{2}$, and $\mathrm{Ag}_{2} \mathrm{FeGeTe}_{4}$ in equilibrium with phases in the adjacent phase regions. Particularly, the calculated Gibbs energies of $\mathrm{Ag}_{2} \mathrm{FeGeTe}_{4}$ in two different adjacent 4-phase regions are consistent, which also indicates that it has stoichiometric composition.
\end{abstract}

Keywords: silver-based compounds; thermoelectric materials; phase equilibria; thermodynamic properties; Gibbs energy; EMF method

\section{Introduction}

Several household devices and industrial applications dissipate considerable amounts of heat. About $60 \%$ of the dissipated heat is below $473 \mathrm{~K}$, therefore, recovering the low temperature waste heat plays a crucial role in improving energy efficiency [1]. Low and intermediate temperature thermoelectric materials (TMs) technology promoting high performance and low materials cost play a key role for enabling energy efficiency through waste heat harvest and utilization [1-3]. Generally, discovery of new functional materials with unique physicochemical properties and a wider thermal stability ranges is one of the main objectives of inorganic materials research. In this regard, ternary and quaternary silver tellurides are good candidate functional materials with unique thermoelectric, photoelectric, non-linear optical, etc. properties [4-6]. Some of these compounds have high conductivity of $\mathrm{Ag}^{+}$ion and can applied in electrochemical data storage devises, electrodes, sensors, etc. $[7,8]$. For instance, the performance of temperature $(\mathrm{T})$ dependent TMs is quantified 
with figure of merit (ZT), which is dimensionless and expressed as $Z T=\sigma S^{2} T \cdot\left(\kappa_{\text {lat }}+\right.$ $\left.\kappa_{\mathrm{el}}\right)^{-1}$, where $\sigma, S, \kappa_{\text {lat }}$, and $\kappa_{\mathrm{el}}$ are the electrical conductivity, Seebeck coefficient, electronic thermal conductivity, and lattice thermal conductivity, respectively $[9,10]$. The search for cost effective new TMs of high ZT is based on phase equilibria data in the respective systems and thermodynamic data of the individual phases in different temperature ranges.

The Ag-Fe system's phase diagram is presented in [11]. The $\mathrm{Fe}_{1+x} \mathrm{Te}(0.067<x<0.17)$ and $\mathrm{FeTe}_{2}$ compounds exist in the system below $770 \mathrm{~K}$ [12]. The structural parameters for the $\mathrm{Fe}_{1.12} \mathrm{Te}$ phase were reported in [13]. The data on the formation of the $\mathrm{AgFeTe}$ compound in the Ag-Fe-Te system are debatable. The existence of the compound is denied in [14-17] due to the 2-phase composition of the ' $\mathrm{AgFeTe}_{2}$ ' samples quenched from the melt at $T=1073 \mathrm{~K}$ and from the range $873-1023 \mathrm{~K}$. It was shown that the synthesis of ' $\mathrm{AgFeTe}_{2}{ }^{\prime}$ resulted in at least two phases of which one is $\mathrm{Ag}_{2} \mathrm{Te}$. The reported experimental results were also confirmed in [18-20], but the authors considered them insufficient to assert the absence of the $\mathrm{AgFeTe}_{2}$ compound in the solid-state part of $T-x$ phase diagram. Physical properties of $\mathrm{AgFeTe}_{2}$ were studied in [20-23]. According to Shtrum [18], $\mathrm{AgFeTe}_{2}$ exists at $T>793 \mathrm{~K}$. Structural characterizations of the $\mathrm{AgFeTe}_{2}$ single crystal quenched from $T$ $=873 \mathrm{~K}$ were performed with X-ray analysis in [19]. The trigonal ordering of the crystal lattice with the parameters $a=0.760 \mathrm{~nm}, c=0.569 \mathrm{~nm}, c / a=0.749, Z=3$ was established. The $\mathrm{AgFeTe}_{2}$ single crystal decomposes into two phases below $773 \mathrm{~K}$. Such solid-state decomposition of compounds is not uncommon. For instance, the decomposition of $\mathrm{CuFeS}_{2}$ at $T=843 \mathrm{~K}$ was established in [24]. Another example is given in [25] where the superionic phase $\mathrm{Ag}_{2} \mathrm{ZnI}_{4}$ exists in two temperature ranges of (300-477) $\mathrm{K}$ and $(538-553) \mathrm{K}$. The obstacle to the formation of equilibrium compounds from metastable heterogeneous phase mixtures at relatively low temperatures $(T<600 \mathrm{~K})$ is the lack of the nucleation centers of a new phase due to the low energy of the thermal motion of atoms [26,27]. Kinetic barrier is eliminated by using the metastable phase mixture as the positive electrode (PE) of electrochemical cell (ECC) [28]. The defining role in these processes belongs to $\mathrm{Ag}^{+}$cations that moved from the negative to the positive electrode and are centers of formation of the equilibrium compounds. Examples of the transition from metastable to equilibrium phases in PE of ECCs are presented in [29-35].

The existence of the only quaternary compound $\mathrm{Ag}_{2} \mathrm{FeGeTe}_{4}$ in the $\mathrm{Fe}-\mathrm{Ag}-\mathrm{Ge}-\mathrm{Te}$ system was reported by [36]. The compound was obtained by cooling the melt mixture of the pure elements in an evacuated ampoule from $T=1420 \mathrm{~K}$. The melt crystallizes at $T=990 \mathrm{~K}$. The homogenization annealing of the crystallized material was performed at $T=770 \mathrm{~K}$ for $1 \mathrm{~h}$, followed by rapid cooling to room temperature. X-ray study of the quenched material revealed that $\mathrm{Ag}_{2} \mathrm{FeGeTe}_{4}$ has orthorhombic lattice with the parameters $a=0.8048 \mathrm{~nm}, b=0.6668 \mathrm{~nm}$, and $c=0.6450 \mathrm{~nm}$. No information on the thermal stability of $\mathrm{Ag}_{2} \mathrm{FeGeTe}_{4}$ below $600 \mathrm{~K}$ was found in the published literature.

The main objective of this experimental research was to reveal the possibilities of solid state synthesis of the equilibrium set of phases from a non-equilibrium mixture of elements and compounds in the $\mathrm{Ag}-\mathrm{Fe}-\mathrm{Ge}-\mathrm{Te}$ system below $600 \mathrm{~K}$. This temperature is also at which the energy of the thermal motion of atoms is not favorable for the nucleation centers of the phase formation; to establish the phase equilibria in the vicinity of synthesized ternaries and quaternary phases; and to determine thermodynamic properties of the $\mathrm{AgFeTe}_{2}$, $\mathrm{Ag}_{2} \mathrm{FeTe}_{2}$, and $\mathrm{Ag}_{2} \mathrm{FeGeTe}_{4}$ compounds. The obtained thermodynamic data can be applied for completing and optimizing phase diagrams of the studied system by applying the CALPHAD method [37,38]. Furthermore, the obtained data can help to control chemical behaviors of the multicomponent compounds in more complex systems; including the ongoing research for substitution of Fe with $\mathrm{Co} / \mathrm{Ni}$, Ge with $\mathrm{Sn}$, and Te with $\mathrm{S} / \mathrm{Se}$, and to synthesis stable phases with high ZT parameter values. 


\section{Materials and Methods}

\subsection{Synthesis and Characterization}

High purity elements, $99.99 \mathrm{wt} \%$ Ag, from Alfa Aesar (Karlsruhe, Germany), $99.9 \mathrm{wt} \%$ Fe also from Alfa Aesar (Karlsruhe, Germany), $99.999 \mathrm{wt} \%$ Ge from Lenreactiv (St. Petersburg, Russia), $99.99 \mathrm{wt} \% \mathrm{~S}$ from Lenreactiv (St. Petersburg, Russia), and $99.99 \mathrm{wt} \%$ Te from Lenreactiv (St. Petersburg, Russia) were used as initial materials for the synthesis of the compounds. The samples of compositions ' $\mathrm{AgFeTe}_{2}$ ' and ' $\mathrm{Ag}_{2} \mathrm{FeGeTe}_{4}$ ' were synthesized for X-ray diffraction (XRD) analysis by:

(1) a carefully weighed mixture of the pure elements were synthesized in evacuated quartz ampoules by annealing at $630 \mathrm{~K}$ for 1 week. Then, the samples were cooled at the rate of $2 \mathrm{~K} \cdot \mathrm{min}^{-1}$ to room temperature and ground to $\sim 5 \mu \mathrm{m}$ particle size. Vacuum homogenization of the fine particles was conducted at $580 \mathrm{~K}$ for a week, and

(2) melting of the appropriately weighed mixture of the pure elements at $1100 \mathrm{~K}$ in vacuum followed with annealing of the finely disperse mixture, also in vacuum, at $580 \mathrm{~K}$ for a week.

Equilibrium phases synthesis for the thermodynamic investigation of $\mathrm{AgFeTe}_{2}, \mathrm{Ag}_{2} \mathrm{FeTe}_{2}$, and $\mathrm{Ag}_{2} \mathrm{FeGeTe}_{4}$ was conducted within the positive electrodes (PEs) of the electrochemical cells (ECCs) at $560 \mathrm{~K}$.

An STOE_STADI_P diffractometer equipped with a linear position-sensitive detector PSD, in a Guinier geometry (transmission mode, $\mathrm{CuK} \alpha_{1}$ radiation, a bent $\mathrm{Ge}(111)$ monochromator, and $2 \theta / \omega$ scan mode) collected the XRD patterns. Preliminary data processing and phase analysis with XRD were conducted with STOE_WinXPOW_3.03 [39] and Powder_Cell_2.4_PC programs [40], applying the data of structures of the compounds adapted from the database [41].

The $\mathrm{Ag}_{2} \mathrm{GeS}_{3}$ glass [42-44] was synthesized by melting appropriately weighed mixtures of the pure elements at $1200 \mathrm{~K}$ and quenching in ice-water.

\subsection{Electromotive Force (EMF) Measurements}

To accomplish accurate thermodynamic measurements by the EMF method [45-49], the following ECC were arranged:

$$
\text { (-)Graphite }\|\mathrm{LE}\| \mathrm{SE}\left\|\mathrm{R}\left[\mathrm{Ag}^{+}\right]\right\| \mathrm{PE} \| \text { Graphite(+), }
$$

where LE is (-) electrode on the left, $\mathrm{SE}$ is the solid-state fast $\mathrm{Ag}^{+}$ions conducting solidelectrolyte, $\mathrm{PE}$ is the (+) electrode on the right, and $\mathrm{R}\left[\mathrm{Ag}^{+}\right]$is the diffusion region of $\mathrm{Ag}^{+}$ into PE. Pure silver in powder form was used as LE. The purely $\mathrm{Ag}^{+}$ion conducting $\mathrm{Ag}_{2} \mathrm{GeS}_{3}$ glass was used as SE [42,50].

PEs of the cells were prepared from a homogenously mixed powder (particles size $\sim 5 \mu \mathrm{m}$ ) composition of the elements $\mathrm{Ag}$, $\mathrm{Fe}$, and $\mathrm{Te}$ (the $\mathrm{Ag}-\mathrm{Fe}-\mathrm{Te}$ system); the elements $\mathrm{Ag}$, $\mathrm{Fe}$, Te and compounds $\mathrm{Ag}_{8} \mathrm{GeTe}_{6}, \mathrm{GeTe}, \mathrm{FeTe}_{2}$ (the $\mathrm{Ag}-\mathrm{Fe}-\mathrm{Ge}-\mathrm{Te}$ system). The ratios of the elements and compounds were calculated from the potential reactions in the considered phase regions. Materials of the ECCs in powder form were poured in a hole with $2 \mathrm{~mm}$ in diameter that was arranged in the fluoroplast matrix and pressed at a pressure of $10^{8} \mathrm{~Pa}$. After pressing, the components had a density of $\rho=(0.93 \pm 0.02) \cdot \rho_{0}$, where $\rho_{0}$ is the experimentally determined density of cast samples [51,52]. The process of forming the equilibrium set of phases in the $\mathrm{R}\left[\mathrm{Ag}^{+}\right]$region for the particle size of the heterogeneous phase mixture $\sim 5 \mu \mathrm{m}$ and $500 \mathrm{~K}$ took $<10 \mathrm{~h}$. The criterion for attaining phase equilibria in the $\mathrm{R}[\mathrm{Ag}+]$ region of PE were; (1) when the EMF values $(E)$ measured at the target equilibration temperature wing around a certain EMF value and (2) the reproducibility of the $E$ vs. $T$ relations of ECCs during the heating-cooling cycles. Due to its negligible amount, it was impossible to detach the equilibrium set of phases from pressed components of ECCs for X-ray diffraction analysis, similar to the one described in $[28,30]$.

Measurements of the EMF were carried out by the compensation method in a resistance furnace situated horizontally similar to the one detailed in [53]. We used a continu- 
ously flowing highly purified $99.9 \% \operatorname{Ar}(\mathrm{g})$ at $p=0.12 \mathrm{MPa}$, as protective atmosphere, with a rate of flowing of $2 \times 10^{-3} \mathrm{~m}^{3} \cdot \mathrm{h}^{-1}$ from the negative to positive electrode of the electrochemical cell. The temperature variation was controlled to be less than $0.1 \%$. The EMF of the cells were measured with high resistance digital voltmeter universal U7-9 and MTech PGP-550M device. Differences in the EMF values at the specific equilibration temperature did not exceed $\Delta E= \pm 0.3 \mathrm{mV}$. The rate of heating and cooling were $2 \mathrm{~K} \cdot \mathrm{min}^{-1}$. More details on the ECCs and procedure of the EMF-measurements are given in our previous publications [54-56].

\section{Results}

\subsection{Thermodynamic Data of the $\mathrm{AgFeTe}_{2}$ and $\mathrm{Ag}_{2} \mathrm{FeTe}_{2}$}

Samples of the compounds 'AgFeTe ${ }_{2}$ ' were synthesized with the methods described in Section 2.1. According to results of XRD analysis, composition of these samples are identical and consists mixture of the $\mathrm{Ag}_{2} \mathrm{Te}$ [57], $\mathrm{FeTe}_{2}$ [58], and $\mathrm{Fe}_{1.12} \mathrm{Te}$ [41] compounds (Figure 1). Increasing the annealing time to 3 weeks did not change the samples' diffraction patterns. Therefore, there are no indication of the formation of the $\mathrm{AgFeTe}_{2}$ compound under the conditions in the synthesis and annealing of the samples in vacuum ampoules, similar to Refs. [13-15].

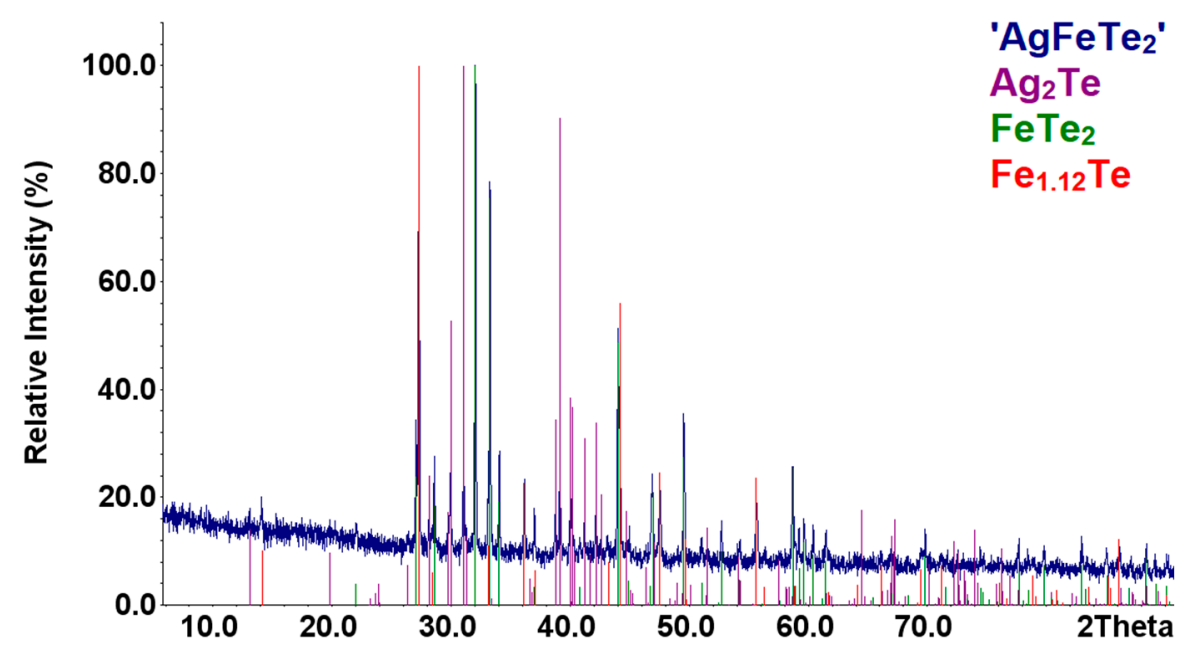

Figure 1. Comparison of the XRD patterns of the sample 'AgFeTe ${ }_{2}^{\prime}$ with those theoretical patterns of the compounds.

The syntheses and thermodynamic investigations of the $\mathrm{AgFeTe}$ and $\mathrm{Ag}_{2} \mathrm{FeTe}_{2} \mathrm{com}$ pounds, as in case of $\mathrm{AgFeSe}_{2}$ and $\mathrm{Ag}_{2} \mathrm{FeSe}_{2}$ [28], were:

(1) Characterized by the XRD method, heterogeneous phase compositions of the 'AgFeTe ${ }_{2}$ ' sample is for kinetic reasons considered metastable below $600 \mathrm{~K}$;

(2) The correctness of the proposed equilibrium concentration space division of the Ag$\mathrm{Fe}-\mathrm{Te}$ system in the part $\mathrm{Ag}_{2} \mathrm{Te}-\mathrm{FeTe}_{2}-\mathrm{Fe}_{1.12} \mathrm{Te}$ (I) into separate 3-phase regions; and

(3) Possibility of the synthesis of set of equilibrium phases, including the $\mathrm{AgFeTe}_{2}$ and $\mathrm{Ag}_{2} \mathrm{FeTe}_{2}$, in the PE of ECCs.

As in the case of the study of formation of equilibrium phase in the Se-Ag-Fe system [28], we analyzed the possibility the existence of $\mathrm{AgFeTe}_{2}$ and $\mathrm{Ag}_{2} \mathrm{FeTe}_{2}$ compounds in the equilibrium phase space of the Ag-Fe-Te system. The compositions $\mathrm{AgFeTe}_{2}$ and $\mathrm{Ag}_{2} \mathrm{FeTe}_{2}$ lay at the intersection points of the tie-lines AgTe-'FeTe', $\mathrm{Ag}-\mathrm{FeTe}_{2}$, and $\mathrm{Ag}_{2} \mathrm{Te}-$ 'FeTe', Ag-FeTe 2 AgTe-Fe, respectively. According to Goryunova [59], ternary compounds are formed at the cross of the sections between binary compounds or binary compounds and elements.

The division of the equilibrium Te-Ag-Fe system's concentration space in the part (I) into 2- and 3-phase regions involving the proposed ternary phases $\mathrm{AgFeTe}_{2}$ and $\mathrm{Ag}_{2} \mathrm{FeTe}_{2}$, 
and the binary compounds of the Ag-Te and Fe-Te systems is plotted in Figure 2. The correctness of the division was confirmed by the following experimental studies. Based on the suggested division of the Ag-Fe-Te system, samples of positive electrodes of the ECCs were prepared in different phase regions. The ratios of the elements Ag:Fe:Te into the 2- and 3phase regions were: 1:2:4 (phase region $\mathrm{FeTe}_{2}-\mathrm{AgFeTe}_{2}$ (II)), 3:2:4 ( $\mathrm{AgFeTe}_{2}-\mathrm{Ag}_{2} \mathrm{FeTe}_{2}$ (III)), 1:3:5 $\left(\mathrm{FeTe}_{2}-\mathrm{Fe}_{1.12} \mathrm{Te}-\mathrm{AgFeTe}\right)_{2}$, 3:2:5 $\left(\mathrm{Ag}_{2} \mathrm{Te}-\mathrm{FeTe}_{2}-\mathrm{AgFeTe}_{2}\right), 3: 3: 5\left(\mathrm{Ag}_{2} \mathrm{FeTe}_{2}-\mathrm{Fe}_{1.12} \mathrm{Te}-\right.$ $\mathrm{AgFeTe} 2)$, and 5:2:5 $\left(\mathrm{Ag}_{2} \mathrm{Te}-\mathrm{Ag}_{2} \mathrm{FeTe}_{2}-\mathrm{AgFeTe}_{2}\right)$, respectively.

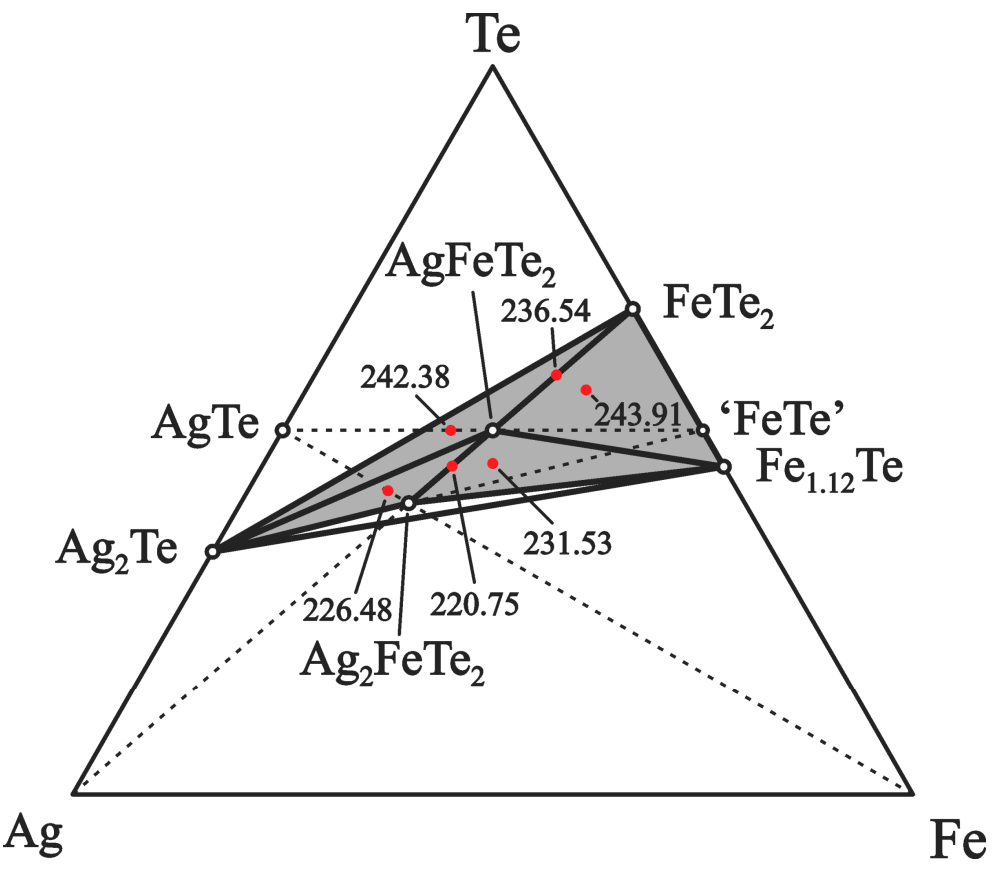

Figure 2. Equilibrium phase relations in the $\mathrm{Ag}-\mathrm{Fe}-\mathrm{Te}$ system below $500 \mathrm{~K}$ in the $\mathrm{Ag}_{2} \mathrm{Te}_{\mathrm{f}}-\mathrm{FeTe}_{2}-$ $\mathrm{Fe}_{1.12} \mathrm{Te}$ (I) part. The dashed and solid tie lines indicate 2-phase equilibria and the red dots indicate phase compositions of the positive electrodes of the ECCs. For some phase regions, EMF values in $\mathrm{mV}$ at $460 \mathrm{~K}$ are given.

In ECCs of the type (A), $\mathrm{Ag}^{+}$ions diffusing from the electrode on the left to the right due to chemical potentials' of silver difference in these regions [60]. The consequence of such dynamics is the existence of a potential difference at the two electrodes. Synthesis of the set of equilibrium phases was conducted in the PE of ECC at the diffusion depth of $\mathrm{Ag}^{+}$ ions, which is the $\mathrm{R}[\mathrm{Ag}+]$ region. Since the $\mathrm{Ag}^{+}$ions are not phases, they do not interact with $\mathrm{PE}$ components chemically. Instead, the $\mathrm{Ag}^{+}$ions served as the nucleation centers for stable phases as well as catalysts for the low temperature synthesis of the equilibrium set of phases [26,28].

The positive electrodes of ECCs with components in the 2- and 3-phase regions are characterized by various EMF values at constant $T$ between 435 and $490 \mathrm{~K}$, Table 1 and Figure 3. The 3-phase region which is further away from the point of $\mathrm{Ag}$ has a higher EMF value. These data validate the suggested division of the concentration space in the Ag-Fe-Te system. 
Table 1. A summary of the measured temperatures and EMF values of the ECCs in different phase regions of the Ag-TeFe system.

\begin{tabular}{|c|c|c|c|c|c|c|}
\hline$T(\mathrm{~K})$ & $\begin{array}{l}\text { Phase Region } \\
\text { FeTe }_{2}-\mathrm{AgFeTe}_{2}\end{array}$ & $\begin{array}{c}\text { Phase Region } \\
\mathrm{AgFeTe}_{2}- \\
\mathrm{Ag}_{2} \mathrm{FeTe}_{2}\end{array}$ & $\begin{array}{c}\text { Phase Region } \\
\mathrm{FeTe}_{2}-\mathrm{Fe}_{1.12} \mathrm{Te}- \\
\mathrm{AgFeTe}_{2}\end{array}$ & $\begin{array}{c}\text { Phase Region } \\
\mathrm{Ag}_{2} \mathrm{Te}_{-} \mathrm{FeTe}_{2}- \\
\mathrm{AgFeTe}_{2}\end{array}$ & $\begin{array}{c}\text { Phase Region } \\
\mathrm{Ag}_{2} \mathrm{FeTe}_{2}- \\
\mathrm{Fe}_{1.12} \mathrm{Te}-\mathrm{AgFeTe}_{2}\end{array}$ & $\begin{array}{c}\text { Phase Region } \\
\mathrm{Ag}_{2} \mathrm{Te}-\mathrm{Ag}_{2} \mathrm{FeTe}_{2}- \\
\mathrm{AgFeTe}_{2}\end{array}$ \\
\hline & $E(\mathrm{mV})$ & $E(\mathrm{mV})$ & $E(\mathrm{mV})$ & $E(\mathrm{mV})$ & $E(\mathrm{mV})$ & $E(\mathrm{mV})$ \\
\hline 435.2 & 231.38 & 212.98 & 239.35 & 237.45 & 223.71 & 218.37 \\
\hline 440.2 & 232.43 & 214.53 & 240.24 & 238.43 & 225.22 & 219.90 \\
\hline 445.2 & 233.36 & 215.96 & 241.17 & 239.27 & 226.80 & 221.62 \\
\hline 450.1 & 234.52 & 217.65 & 242.02 & 240.31 & 228.54 & 223.29 \\
\hline 455.1 & 235.47 & 219.27 & 242.87 & 241.33 & 229.88 & 224.82 \\
\hline 460.0 & 236.54 & 220.75 & 243.91 & 242.38 & 231.53 & 226.48 \\
\hline 465.0 & 237.62 & 222.37 & 244.85 & 243.42 & 233.12 & 228.23 \\
\hline 469.9 & 238.66 & 223.94 & 245.78 & 244.45 & 234.62 & 229.62 \\
\hline 474.8 & 239.74 & 225.38 & 246.72 & 245.43 & 236.09 & 231.09 \\
\hline 479.9 & 240.78 & 226.86 & 247.65 & 246.45 & 237.75 & 232.90 \\
\hline 484.5 & 241.65 & 228.47 & 248.44 & 247.48 & 239.18 & 234.39 \\
\hline 490.2 & 242.94 & 230.19 & 249.62 & 248.65 & 240.99 & 236.25 \\
\hline
\end{tabular}

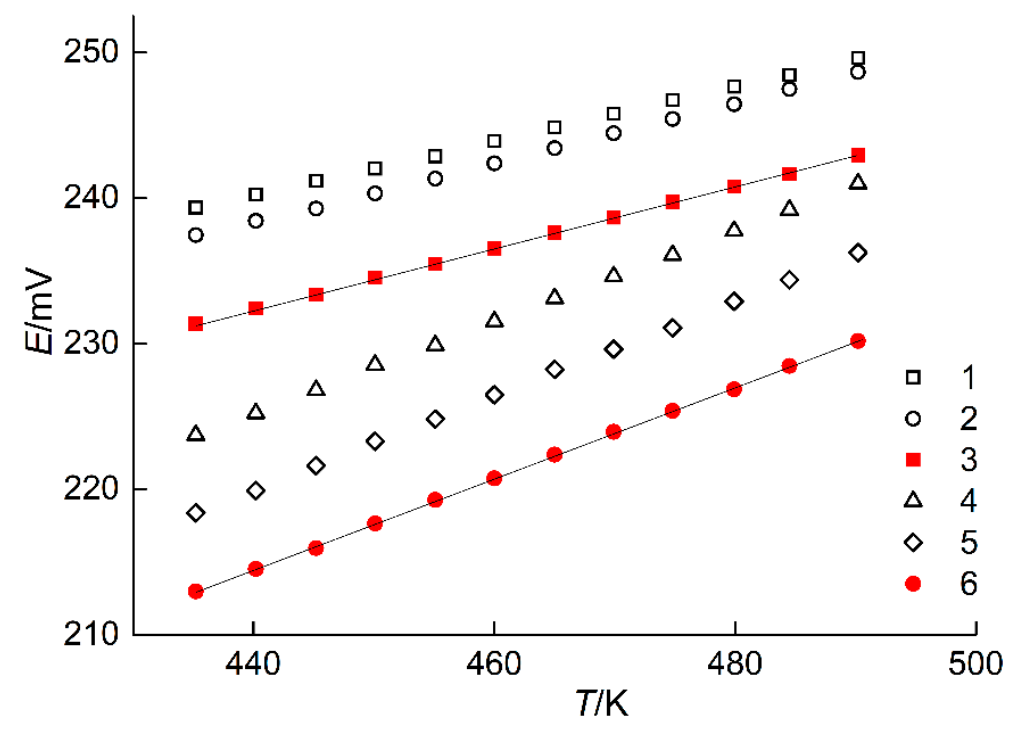

Figure 3. Dependences $E$ vs. $T$ of the ECCs constituting positive electrodes of phase assemblages: $\mathrm{FeTe}_{2}-\mathrm{Fe}_{1.12} \mathrm{Te}-\mathrm{AgFeTe}_{2}$ (1), $\mathrm{Ag}_{2} \mathrm{Te}-\mathrm{FeTe}_{2}-\mathrm{AgFeTe}_{2}$ (2), $\mathrm{FeTe}_{2}-\mathrm{AgFeTe}_{2}$ (3), $\mathrm{Ag}_{2} \mathrm{FeTe}_{2}-\mathrm{Fe}_{1.12} \mathrm{Te}-$ $\mathrm{AgFeTe}_{2}(4), \mathrm{Ag}_{2} \mathrm{Te}-\mathrm{Ag}_{2} \mathrm{FeTe}_{2}-\mathrm{AgFeTe}_{2}$ (5), and $\mathrm{AgFeTe}{ }_{2}-\mathrm{Ag}_{2} \mathrm{FeTe}_{2}$ (6).

The division of (I) relative to the position of silver, shown in Figure 2, can be applied for the determination of the thermodynamic properties of the $\mathrm{AgFeTe}_{2}$ and $\mathrm{Ag}_{2} \mathrm{FeTe}_{2}$ by the EMF method [60]. The overall potential forming reactions can be expressed as:

$$
\begin{gathered}
\mathrm{Ag}+\mathrm{FeTe}_{2}=\mathrm{AgFeTe}, \\
\mathrm{Ag}+\mathrm{AgFeTe}_{2}=\mathrm{Ag}_{2} \mathrm{FeTe}_{2} .
\end{gathered}
$$

The (R1) and (R2) reactions were realized in PE of the phase regions (II) and (III), respectively.

The analyses of the $E$ vs. $T$ relations for reactions (R1) and (R2) between 435 and $490 \mathrm{~K}$ was carried out by the least-squares method [60-62] using Equation (1):

$$
E=a+b T \equiv \bar{E}+b(T-\bar{T})
$$


where $\bar{E}=\frac{\sum E_{i}}{n}, \bar{T}=\frac{\sum T_{i}}{n}\left(E_{i}\right.$ is the EMF of ECC at temperature $T_{i} ; n$ is number of experimental pairs $E_{i}$ and $T_{i}$ ).

Coefficients $b$ and $a$ were calculated by the following Equations (2) and (3):

$$
\begin{gathered}
b=\frac{\sum\left[\left(E_{i}-\bar{E}\right)\left(T_{i}-\bar{T}\right)\right]}{\sum\left(T_{i}-\bar{T}\right)^{2}}, \\
a=\bar{E}-b \bar{T} .
\end{gathered}
$$

The measurement uncertainties' statistical dispersions consisted of the determination of variances of the experimental EMF, $E\left(u_{E}^{2}\right)$, coefficients $b\left(u_{b}^{2}\right)$ and $a\left(u_{a}^{2}\right)$, and the dispersions of the calculated EMF according to Equation (1) $\widetilde{E}\left(u_{\widetilde{E}}^{2}\right)$ :

$$
\begin{gathered}
u_{E}^{2}=\frac{\sum\left(E_{i}-\widetilde{E}_{i}\right)^{2}}{n-2}, \\
u_{b}^{2}(T)=\frac{u_{E}^{2}}{\sum\left(T_{i}-\bar{T}\right)^{2}}, \\
u_{a}^{2}(T)=\frac{u_{E}^{2}}{n}+\frac{u_{E}^{2} \bar{T}^{2}}{\sum\left(T_{i}-\bar{T}\right)^{2}}, \\
u_{\widetilde{E}}^{2}(T)=\frac{u_{E}^{2}}{n}+u_{b}^{2}(T-\bar{T})^{2} .
\end{gathered}
$$

Equation (8) was applied to calculate the corresponding uncertainties $\left(\Delta_{i}\right)$ :

$$
\Delta_{i}=k_{S t} u_{i}
$$

where $k_{S t}$ is the Student's coefficient, and $u_{i}$ is the standard deviation. Student's coefficient is $k_{S t}=2.179$ when $n=12$ and with the confidence level of $95 \%$ [63].

The overall equation of the $E$ as a function of $T$ together with the statistical dispersions can be express as $[48,64]$ :

$$
E=a+b T \pm k_{S t} \sqrt{\left(\frac{u_{E}^{2}}{n}+u_{b}^{2}(T-\bar{T})^{2}\right)} .
$$

Presented in Table 1 experimental values of the EMF and temperature were used to calculate the coefficients and dispersions of Equation (9) for the (II) and (III) phase regions. The obtained results are listed in Table 2.

Table 2. EMF vs. temperature relations for the type (A) ECCs in the (II) and (III) phase regions of the Fe-Ag-Ge-Te system, in the temperature range between 435 and $490 \mathrm{~K}$. The coefficients $a$ and $b$ were obtained through the linear least squares analysis of the $E M F$ vs. $T$ measuremnt data, $n$ is the number of experimental points, $k_{S t}$ is Student's coefficient with the level of confidence $95 \%$.

\begin{tabular}{cc} 
Phase Region & $\boldsymbol{E}=\boldsymbol{a}+\boldsymbol{b} \boldsymbol{T} \pm \boldsymbol{k}_{S t} \sqrt{\left(\frac{\boldsymbol{u}_{E}^{2}}{\boldsymbol{n}}+\boldsymbol{u}_{\boldsymbol{b}}^{2}(\boldsymbol{T}-\boldsymbol{T})\right)}$ \\
\hline (II) & $E_{(\mathrm{II})}=139.72+210.52 \times 10^{-3} T \pm 2.179 \sqrt{\left(\frac{2.65 \times 10^{-3}}{12}+7.53 \times 10^{-7}(T-462.51)^{2}\right)}$ \\
(III) & $E_{(\mathrm{III})}=76.43+313.73 \times 10^{-3} T \pm 2.179 \sqrt{\left(\frac{5.44 \times 10^{-3}}{12}+1.54 \times 10^{-6}(T-462.51)^{2}\right)}$ \\
\hline
\end{tabular}


The Gibbs energies, enthalpies and entropies of reactions (R1) and (R2) can be calculated by applying the measured EMF of each ECCs as a function of temperature in the fundamental Equations (10)-(12):

$$
\begin{gathered}
\Delta_{\mathrm{r}} G=-z \cdot \mathrm{F} \cdot E, \\
\Delta_{\mathrm{r}} H=-z \cdot \mathrm{F} \cdot[E-(d E / d T) \cdot T], \\
\Delta_{\mathrm{r}} S=z \cdot \mathrm{F} \cdot(d E / d T),
\end{gathered}
$$

where $z=1$ is the number of electrons participated in reactions (R1) and (R2), F is Faraday's constant $\left(96,485.33 \mathrm{C} \cdot \mathrm{mol}^{-1}\right)$, and $E$ in $\mathrm{V}$ is the EMF of the ECCs.

The thermodynamic functions of the reactions (R1) and (R2) at $298 \mathrm{~K}$ were determined using Equations (10)-(12) by approximating $\left(\frac{\partial \Delta_{\mathrm{r}} H}{\partial T}\right)_{p}=0$ and $\left(\frac{\partial \Delta_{\mathrm{r}} S}{\partial T}\right)_{p}=0[29,65]$. The determined results are collected in Table 3.

Table 3. Standard thermodynamic quantities of the reactions (R1) and (R2) in the ECCs at $298 \mathrm{~K}$.

\begin{tabular}{cccc}
\hline \multirow{2}{*}{ Reaction } & $-\boldsymbol{\Delta}_{\boldsymbol{r}} \boldsymbol{G}^{\circ}$ & $-\boldsymbol{\Delta}_{\boldsymbol{r}} \mathbf{H}^{\circ}$ & $\boldsymbol{\Delta}_{\boldsymbol{r}} \boldsymbol{S}^{\circ}$ \\
\cline { 2 - 4 } & \multicolumn{2}{c}{$\mathbf{~} \mathbf{k J} \cdot \mathbf{m o l}^{-\mathbf{1}}$} & $\mathbf{J} \cdot(\mathbf{m o l} \cdot \mathbf{K})^{-\mathbf{1}}$ \\
\hline (R1) & $19.53 \pm 0.03$ & $13.48 \pm 0.08$ & $20.31 \pm 0.18$ \\
$(\mathrm{R} 2)$ & $16.39 \pm 0.04$ & $7.37 \pm 0.12$ & $30.27 \pm 0.26$ \\
\hline
\end{tabular}

Standard thermodynamic functions of reaction (R1) are related to the thermodynamic functions of formation of the phases and pure elements by Equations (13)-(18):

$$
\begin{aligned}
& \Delta_{\mathrm{r}(\mathrm{R} 1)} G=\Delta_{\mathrm{f}} G_{\mathrm{AgFeTe}_{2}}-\Delta_{\mathrm{f}} G_{\mathrm{FeTe}_{2}} \\
& \Delta_{\mathrm{r}(\mathrm{R} 1)} H=\Delta_{\mathrm{f}} H_{\mathrm{AgFeTe}_{2}}-\Delta_{\mathrm{f}} H_{\mathrm{FeTe}_{2}} \\
& \Delta_{\mathrm{r}(\mathrm{R} 1)} S=S_{\mathrm{AgFeTe}_{2}}-S_{\mathrm{Ag}}-S_{\mathrm{FeTe}_{2}} .
\end{aligned}
$$

It follows from Equations (13)-(15) that:

$$
\begin{aligned}
& \Delta_{\mathrm{f}} G_{\mathrm{AgFeTe}_{2}}=\Delta_{\mathrm{f}} G_{\mathrm{FeTe}_{2}}+\Delta_{\mathrm{r}(\mathrm{R} 1)} G, \\
& \Delta_{\mathrm{f}} H_{\mathrm{AgFeTe}_{2}}=\Delta_{\mathrm{f}} H_{\mathrm{FeTe}_{2}}+\Delta_{\mathrm{r}(\mathrm{R} 1)} H, \\
& S_{\mathrm{AgFeTe}_{2}}=S_{\mathrm{Ag}}+S_{\mathrm{FeTe}_{2}}+\Delta_{\mathrm{r}(\mathrm{R} 1)} S .
\end{aligned}
$$

\begin{tabular}{|c|c|c|c|c|}
\hline \multirow{2}{*}{ Phases } & $-\Delta_{f} G^{\circ}$ & $-\Delta_{f} H^{\circ}$ & $S^{\circ}$ & \multirow{2}{*}{ [Ref.] } \\
\hline & \multicolumn{2}{|c|}{$\mathrm{kJ} \cdot \mathrm{mol}^{-1}$} & $\mathrm{~J} \cdot(\mathrm{mol} \cdot \mathrm{K})^{-1}$ & \\
\hline $\mathrm{Ag}$ & 0 & 0 & 42.677 & [66] \\
\hline $\mathrm{Fe}$ & 0 & 0 & 27.280 & [66] \\
\hline $\mathrm{FeTe}_{2}$ & 64.599 & 72.383 & 100.165 & [66] \\
\hline $\mathrm{AgFeTe}_{2}$ & $84.13 \pm 1.03$ & $85.86 \pm 1.08$ & $163.15 \pm 1.19$ & This work \\
\hline $\mathrm{Ag}_{2} \mathrm{FeTe}_{2}$ & $100.53 \pm 1.07$ & $93.23 \pm 1.21$ & $236.10 \pm 1.46$ & This work \\
\hline
\end{tabular}

The corresponding reactions to determine $\Delta_{\mathrm{f}} G, \Delta_{\mathrm{f}} H$, and $S$ for the $\mathrm{Ag}_{2} \mathrm{FeTe}_{2}$ compound can be written similar to Equations (16)-(18) with their appropriate stoichiometric numbers.

By combining Equations (16)-(18) and thermodynamic data for $\mathrm{Ag}$ and $\mathrm{FeTe}_{2}$ [66], the formation standard Gibbs energies of the $\mathrm{AgFeTe}_{2}$ and $\mathrm{Ag}_{2} \mathrm{FeTe}_{2}$ compounds have been calculated for the first time. The results of the calculations are shown in Table 4.

Table 4. A summary of the standard thermodynamic quantities of selected phases in the Ag-Fe-Te system at $298 \mathrm{~K}$. 
The Gibbs energies of formations of the $\mathrm{AgFeTe}_{2}$ and $\mathrm{Ag}_{2} \mathrm{FeTe}_{2}$ compounds as functions of temperature are described by the following equations as:

$$
\begin{gathered}
\Delta_{\mathrm{f}} G_{\mathrm{AgFeT}_{2}} /\left(\mathrm{kJ} \cdot \mathrm{mol}^{-1}\right)=-(85.86 \pm 1.08)+(5.80 \pm 0.17) \times 10^{-3} \mathrm{~T} / \mathrm{K}, \\
\Delta_{\mathrm{f}} G_{\mathrm{Ag}_{2} \mathrm{FeTe}_{2}} /\left(\mathrm{kJ} \cdot \mathrm{mol}^{-1}\right)=-(93.23 \pm 1.21)-(24.48 \pm 0.51) \times 10^{-3} \mathrm{~T} / \mathrm{K} .
\end{gathered}
$$

\subsection{Thermodynamic Properties of the $\mathrm{Ag}_{2} \mathrm{FeGeTe}_{4}$ Compound}

The samples of the formula composition ' $\mathrm{Ag}_{2} \mathrm{FeGeTe}_{4}{ }^{\prime}$ were obtained by both methods described in Section 2.1 above. For both samples, the diffraction patterns are identical (see Figure 4). The presence of the phases $\mathrm{Ag}_{8} \mathrm{GeTe}_{6}, \mathrm{FeTe}_{2}, \mathrm{GeTe}$, and impurities of the fourth unidentified phase in the samples was identified by XRD. Heat treatment of the finely disperse mixture of the phases in vacuum and in the range between 450 and $600 \mathrm{~K}$ did not affect samples' phase composition.

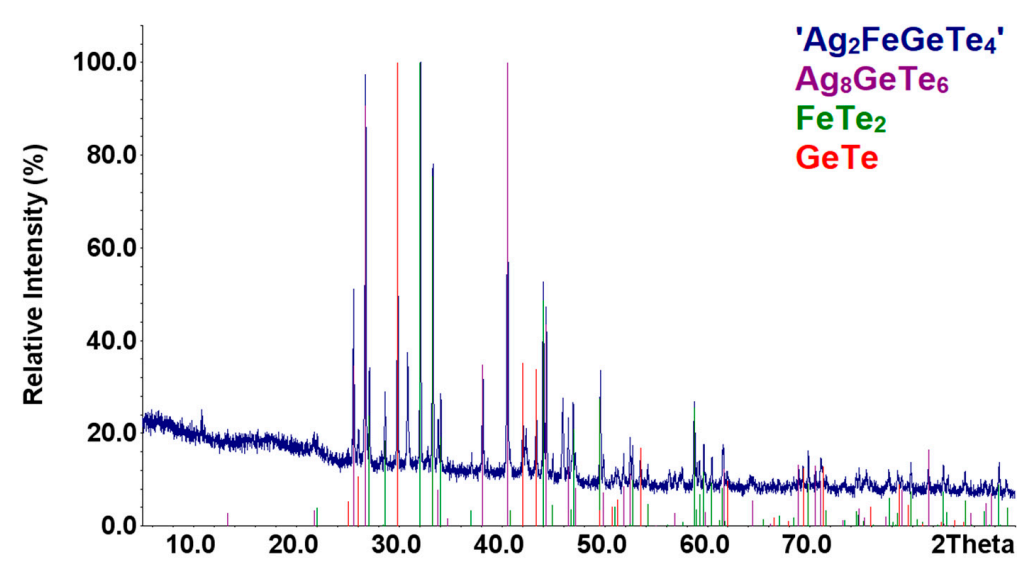

Figure 4. XRD patterns of the sample ' $\mathrm{Ag}_{2} \mathrm{FeGeTe}_{4}$ ' as compared with those theoretical patterns of the compounds.

As in the case of the $\mathrm{AgFeTe}_{2}$ and $\mathrm{Ag}_{2} \mathrm{FeTe}_{2}$ compounds (Section 3.1), investigation of thermodynamic properties of the $\mathrm{Ag}_{2} \mathrm{FeGeTe}_{4}$ in this work were on the following reasons:

(a) below $600 \mathrm{~K}$, composition of the samples of the concentration triangle $\mathrm{Ag}_{8} \mathrm{GeTe}_{6}-$ $\mathrm{FeTe}_{2}-\mathrm{GeTe}$ in the $\mathrm{Ag}-\mathrm{Fe}-\mathrm{Ge}-\mathrm{Te}$ system as the mixture of $\mathrm{Ag}_{8} \mathrm{GeTe}_{6}, \mathrm{FeTe}_{2}$, and GeTe compounds is considered to be metastable for kinetic reasons,

(b) possibility of the $\mathrm{Ag}_{2} \mathrm{FeGeTe}_{4}$ synthesis, similar to the synthesis of the $\mathrm{AgFeTe}_{2}$ and $\mathrm{Ag}_{2} \mathrm{FeTe}_{2}$ compounds into the PE of ECC, and

(c) correctness of the division of the equilibrium concentration space $\mathrm{Fe}-\mathrm{Ag}-\mathrm{Te}-\mathrm{Ge}$ system in the $\mathrm{Ag}_{8} \mathrm{GeTe}_{6}-\mathrm{GeTe}-\mathrm{FeTe}_{2}-\mathrm{AgFeTe}_{2}-\mathrm{Ag}_{8} \mathrm{GeTe}_{6}$ part into separate 4-phase regions: $\mathrm{Ag}_{8} \mathrm{GeTe}_{6}-\mathrm{Ag}_{2} \mathrm{FeGeTe}_{4}-\mathrm{GeTe}-\mathrm{AgFeTe}{ }_{2}$ (IV), $\mathrm{Ag}_{8} \mathrm{GeTe}_{6}-\mathrm{Ag}_{2} \mathrm{FeGeTe}_{4}-\mathrm{GeTe}-$ $\mathrm{FeTe}_{2}(\mathbf{V}), \mathrm{Ag}_{8} \mathrm{GeTe}_{6}-\mathrm{Ag}_{2} \mathrm{FeGeTe}_{4}-\mathrm{AgFeTe}_{2}-\mathrm{FeTe}_{2}$, and $\mathrm{GeTe}-\mathrm{Ag}_{2} \mathrm{FeGeTe}_{4}-\mathrm{AgFeTe}_{2}-$ $\mathrm{FeTe}_{2}$.

The phase equilibria of the $\mathrm{Fe}-\mathrm{Ag}-\mathrm{Te}-\mathrm{Ge}$ system in the part $\mathrm{Ag}_{8} \mathrm{GeTe}_{6}-\mathrm{GeTe}-\mathrm{FeTe}_{2}-$ $\mathrm{AgFeTe}_{2}-\mathrm{Ag}_{8} \mathrm{GeTe}_{6}$ are shown in Figure 5.

The concentration space's division into separate regions was performed with the information presented in $[36,54,67]$ as well as this work. Validity of the proposed limits of 4-phase regions is done by the following calculations of thermodynamic values of the $\mathrm{Ag}_{2} \mathrm{FeGeTe}_{4}$ compound.

The position of the phase regions (IV) and (V) relative to Ag was used to express the equations of the overall reactions of decomposition and synthesis of the 4-component compound: 


$$
\begin{gathered}
3 \mathrm{Ag}+5 \mathrm{Ag}_{2} \mathrm{FeGeTe}_{4}=\mathrm{Ag}_{8} \mathrm{GeTe}_{6}+5 \mathrm{AgFeTe}_{2}+4 \mathrm{GeTe}, \\
2 \mathrm{Ag}+\mathrm{Ag}_{8} \mathrm{GeTe}_{6}+4 \mathrm{GeTe}+5 \mathrm{FeTe}_{2}=5 \mathrm{Ag}_{2} \mathrm{FeGeTe}_{4} .
\end{gathered}
$$

According to the reactions (R3) and (R4), the phase compositions of the positive electrodes in the phase regions (IV) and (V) were determined by element ratios Ag:Fe:Ge:Te of 23:10:10:40 and 18:10:10:40, respectively. The compositions of the PE are marked in Figure 5 by red circles and are located on the $\mathrm{Ag}-\mathrm{Ag}_{2} \mathrm{FeGeTe}_{4}$ ray-line of the $\mathrm{Ag}-\mathrm{Fe}-\mathrm{Ge}-\mathrm{Te}$ tetrahedron, on both sides of the $\mathrm{Ag}_{2} \mathrm{FeGeTe}_{4}$ composition. The PE samples ' $\mathrm{Ag}_{2.3} \mathrm{FeGeTe}_{4}$ ' and ' $\mathrm{Ag}_{1.8} \mathrm{FeGeTe}_{4}$ ' were obtained by melting a mixture of pure elements at $1100 \mathrm{~K}$ and heat treatment of the mixture at $580 \mathrm{~K}$ in vacuum for 1 week.

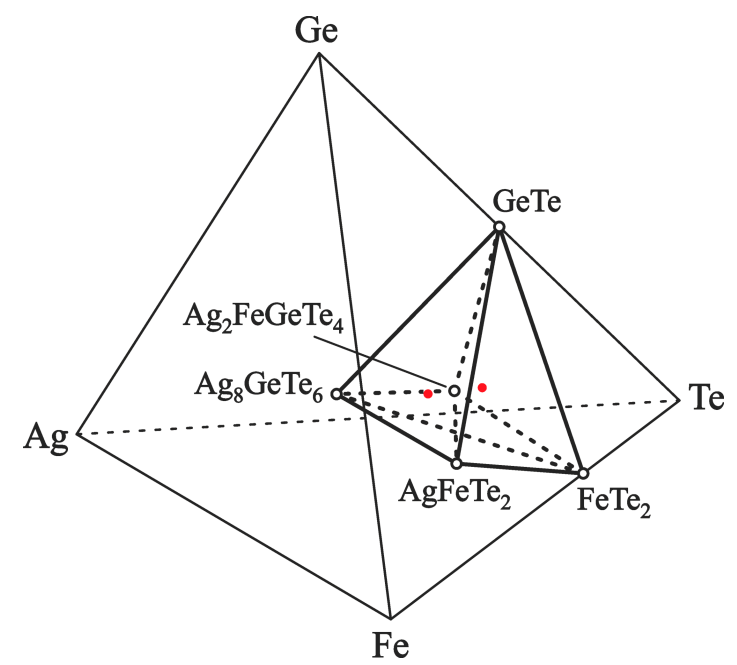

Figure 5. The equilibrium phases in the Fe-Ag-Te-Ge system in the $\mathrm{Ag}_{8} \mathrm{GeTe}_{6}-\mathrm{FeTe}_{2}-\mathrm{GeTe}-\mathrm{AgFe} \mathrm{Te}_{2}-$ $\mathrm{Ag}_{8} \mathrm{GeTe}_{6}$ part, below $550 \mathrm{~K}$. The dashed and solid tie lines show the 2-phase equilibria, the red closed circle show compositions of positive electrodes of ECCs, and the open circle show compounds.

The measured EMF values of the ECCs at various temperatures are presented in Table 5 and plotted in Figure 6. These data were used to calculate the coefficients and dispersions of Equation (9) for the phase regions (IV) and (V). Results of calculations are listed in Table 6.

Table 5. A summary of the measured temperatures and EMF values of the ECCs in different phase regions of the $\mathrm{Fe}-\mathrm{Te}-\mathrm{Ag}$ system.

\begin{tabular}{ccc}
\hline $\boldsymbol{T}(\mathbf{K})$ & $\boldsymbol{E}_{[\text {Phase Region }(\mathrm{IV})]}(\mathbf{m V})$ & $\boldsymbol{E}_{[\text {Phase Region }(\mathbf{V}]}(\mathbf{m V})$ \\
\hline 482.2 & 243.51 & 248.45 \\
484.7 & 244.11 & 248.91 \\
487.1 & 244.71 & 249.29 \\
489.6 & 245.24 & 249.72 \\
492.1 & 245.74 & 250.20 \\
494.5 & 246.47 & 250.72 \\
497.0 & 246.99 & 251.01 \\
499.4 & 247.58 & 251.59 \\
501.9 & 248.31 & 251.88 \\
504.3 & 248.92 & 252.41 \\
506.8 & 249.51 & 252.75 \\
509.2 & 250.14 & 253.12 \\
511.7 & 250.72 & 253.65 \\
514.1 & 251.47 & 254.05 \\
516.6 & 252.09 & 254.38 \\
519.0 & 252.81 & 254.86 \\
\hline
\end{tabular}




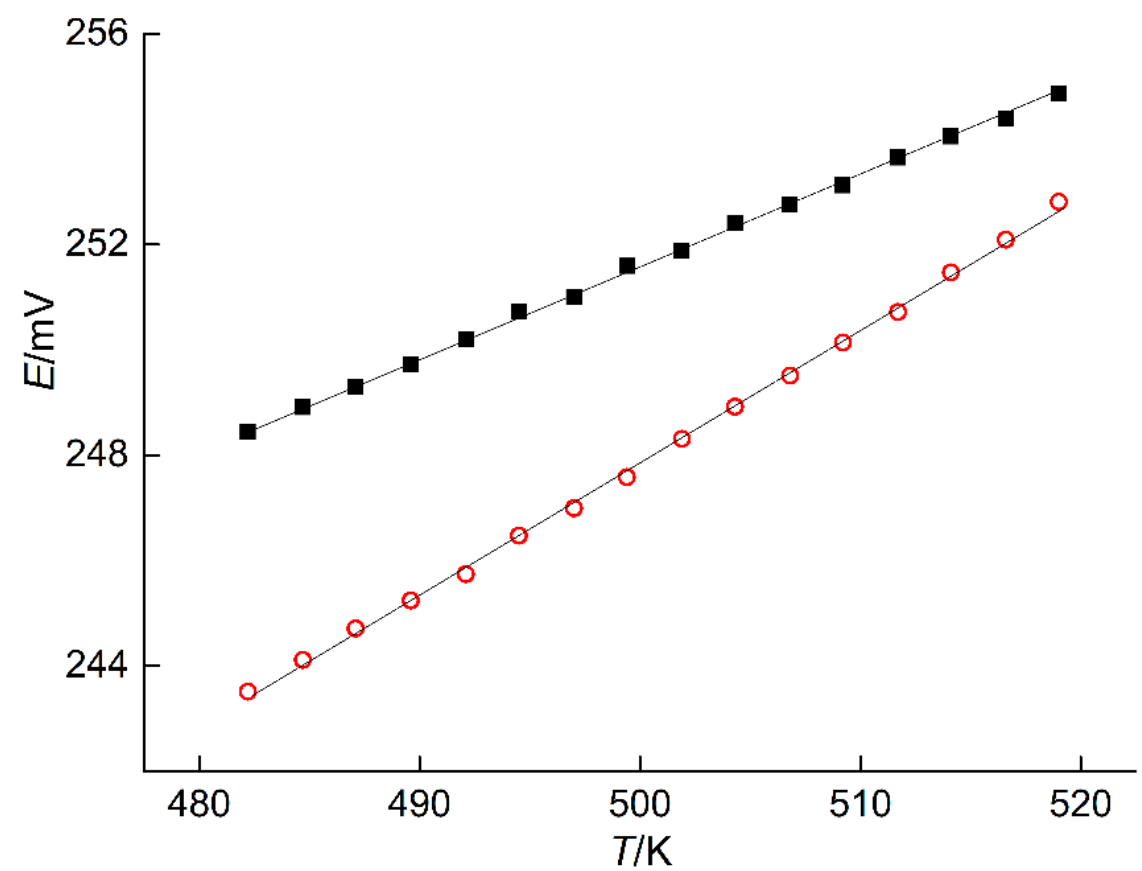

Figure 6. EMF versus temperature obtained with the ECCs incorporating PE in the phase regions (IV)-red open circles and (V)-closed square.

Table 6. EMF vs. temperature relations for the type (A) ECCs in the (IV) and (V) phase regions of the Fe-Ag-Te-Ge system, in the temperature range between 482 and $519 \mathrm{~K}$. The coefficients $a$ and $b$ were determined through linear least squares analysis of the measurements, $n$ is the number of successful experimental points, $k_{S t}$ is Student's coefficient with a level of confidence of $95 \%$.

\begin{tabular}{cc} 
Phase Region & $\boldsymbol{E}=\boldsymbol{a}+\boldsymbol{b} \boldsymbol{T} \pm \boldsymbol{k}_{\boldsymbol{S t}} \sqrt{\left(\frac{\left.\boldsymbol{u}_{\mathrm{L}}^{2}+\boldsymbol{u}_{\boldsymbol{b}}^{2}(\boldsymbol{T}-\boldsymbol{T})\right)}{\mathbf{n}}\right)}$ \\
\hline$(\mathrm{IV})$ & $E_{(\mathrm{IV})}=122.15+251.42 \times 10^{-3} T \pm 2.120 \sqrt{\left(\frac{9.41 \times 10^{-3}}{16}+4.60 \times 10^{-6}(T-500.64)^{2}\right)}$ \\
$(\mathrm{V})$ & $E_{(\mathrm{V})}=164.64+173.88 \times 10^{-3} T \pm 2.120 \sqrt{\left(\frac{3.71 \times 10^{-3}}{16}+1.81 \times 10^{-6}(T-500.64)^{2}\right)}$ \\
\hline
\end{tabular}

The thermodynamic quantities of the reactions (R3) and (R4) were calculated by combining the experimental EMF of each ECC and the Equations (10)-(12). The calculated results are listed in Table 7.

Table 7. Standard thermodynamic quantities of reactions (R3) and (R4) in the ECCs.

\begin{tabular}{cccc}
\hline \multirow{2}{*}{ Reaction } & $-\Delta_{r} G^{\circ}$ & $-\Delta_{r} \mathbf{H}^{\circ}$ & $\Delta_{r} S^{\circ}$ \\
\cline { 2 - 4 } & \multicolumn{2}{c}{$\mathbf{~ k J \cdot \mathbf { m o l } ^ { - \mathbf { 1 } }}$} & $\mathbf{J} \cdot \mathbf{( m o l} \cdot \mathbf{K})^{-\mathbf{1}}$ \\
\hline (R3) & $57.05 \pm 0.27$ & $35.35 \pm 0.66$ & $72.77 \pm 1.32$ \\
$($ R4) & $41.77 \pm 0.11$ & $31.77 \pm 0.28$ & $33.55 \pm 0.55$ \\
\hline
\end{tabular}

The corresponding reactions to determine $\Delta_{\mathrm{f}} G, \Delta_{\mathrm{f}} H$, and $S$ for the $\mathrm{Ag}_{2} \mathrm{FeGeTe}_{4}$ in the phase regions (IV) and (V) can be written similar to Equations (16)-(18) for the AgFeTe 2 compound with their appropriate stoichiometric numbers. Considering thermodynamic data of the pure elements [66], and compounds GeTe [66], $\mathrm{Ag}_{8} \mathrm{GeTe}_{6}$ [60], the standard Gibbs energies of formations of the $\mathrm{Ag}_{2} \mathrm{FeGeTe}_{4}$ in the phase regions (IV) and (V) were described as: 


$$
\begin{gathered}
\Delta_{\mathrm{f}} G_{\mathrm{Ag}_{2} \mathrm{FeGeTe}_{4},(\mathrm{IV})} /\left(\mathrm{kJ} \cdot \mathrm{mol}^{-1}\right)=-(166.6 \pm 2.6)-(2.59 \pm 0.04) \times 10^{-3} \mathrm{~T} / \mathrm{K}, \\
\Delta_{\mathrm{f}} G_{\mathrm{Ag}_{2} \mathrm{FeGeTe}_{4},(\mathrm{~V})} /\left(\mathrm{kJ} \cdot \mathrm{mol}^{-1}\right)=-(166.5 \pm 2.5)-(3.54 \pm 0.05) \times 10^{-3} \mathrm{~T} / \mathrm{K} .
\end{gathered}
$$

A summary of the calculation results with the reported literature data is shown in Table 8.

Table 8. The Standard thermodynamic quantities of the selected elements and compounds in the

\begin{tabular}{|c|c|c|c|c|}
\hline \multirow{2}{*}{ Phases } & $-\Delta_{f} G^{\circ}$ & $-\Delta_{f} H^{\circ}$ & $S^{\circ}$ & \multirow{2}{*}{ [Ref.] } \\
\hline & \multicolumn{2}{|c|}{$\mathrm{kJ} \cdot \mathrm{mol}^{-1}$} & $\mathrm{~J} \cdot(\mathrm{mol} \cdot \mathrm{K})^{-1}$ & \\
\hline $\mathrm{Ge}$ & 0 & 0 & 31.087 & {$[66]$} \\
\hline $\mathrm{Te}$ & 0 & 0 & 49.497 & [66] \\
\hline GeTe & 51.328 & 48.534 & 89.956 & [66] \\
\hline $\mathrm{Ag}_{8} \mathrm{GeTe}_{6}$ & $268.0 \pm 1.0$ & $245.0 \pm 7.0$ & $746.6 \pm 17.1$ & [60] \\
\hline $\mathrm{Ag}_{2} \mathrm{FeGeTe}_{4}{ }^{\mathrm{a}}$ & $167.4 \pm 2.3$ & $166.6 \pm 2.6$ & $344.3 \pm 4.9$ & This work \\
\hline $\mathrm{Ag}_{2} \mathrm{FeGeTe}_{4} \mathrm{~b}$ & $167.6 \pm 2.2$ & $166.5 \pm 2.5$ & $345.2 \pm 4.5$ & This work \\
\hline
\end{tabular}
$\mathrm{Ag}-\mathrm{Fe}-\mathrm{Ge}-\mathrm{Te}$ system at $298 \mathrm{~K}$.

${ }^{\mathrm{a}}$ phase region $(\mathrm{IV}){ }^{\mathrm{b}}$ phase region $(\mathrm{V})$.

The $\Delta_{\mathrm{f}} \mathrm{G}$ values of the $\mathrm{Ag}_{2} \mathrm{FeGeTe}_{4}$ were determined from the EMF measurements into two independent potential forming processes, the $\mathrm{Ag}_{2} \mathrm{FeGeTe}_{4}$ decomposition into $\mathrm{Ag}_{8} \mathrm{GeTe}_{6}, \mathrm{AgFeTe}_{2}$, and $\mathrm{GeTe}$ and in the phase region (IV), and the synthesis of $\mathrm{Ag}_{2} \mathrm{FeGeTe}_{4}$ from $\mathrm{Ag}_{8} \mathrm{GeTe}_{6}, \mathrm{GeTe}$, and $\mathrm{FeTe}_{2}$ in the phase region (V). These processes include all compounds of the investigated concentration space $\mathrm{Ag}_{8} \mathrm{GeTe}_{6}-\mathrm{GeTe}-\mathrm{FeTe}_{2}-\mathrm{AgFeTe}_{2}-$ $\mathrm{Ag}_{8} \mathrm{GeTe}_{6}$. It follows from the data presented in Table 6 that the calculated values of $\Delta_{\mathrm{f}} \mathrm{G}$ for $\mathrm{Ag}_{2} \mathrm{FeGeTe}_{4}$ in these phase regions converge within the experiment error of (the relative difference is less $1 \%$ ). It validates:

(a) phase compositions and divisions of the equilibrium concentration spaces of the $\mathrm{Ag}-\mathrm{Fe}-\mathrm{Te}$ system in the part $\mathrm{Ag}_{2} \mathrm{Te}-\mathrm{FeTe}_{2}-\mathrm{Fe}_{1.12} \mathrm{Te}$ and the $\mathrm{Fe}-\mathrm{Ag}-\mathrm{Te}-\mathrm{Ge}$ system in the part $\mathrm{Ag}_{8} \mathrm{GeTe}_{6}-\mathrm{FeTe}_{2}-\mathrm{GeTe}-\mathrm{AgFeTe}_{2}-\mathrm{Ag}_{8} \mathrm{GeTe}_{6}$,

(b) determined values of thermodynamic functions of the $\mathrm{AgFeTe}_{2}$ and $\mathrm{Ag}_{2} \mathrm{FeGeTe}_{4}$ compounds,

(c) reliability of the thermodynamic data of $\mathrm{GeTe}, \mathrm{FeTe}_{2}$, and $\mathrm{Ag}_{8} \mathrm{GeTe}_{6}$ in the literature, and

(d) the narrow homogeneity region of the $\mathrm{Ag}_{2} \mathrm{FeGeTe}_{4}$.

\section{Conclusions}

The equilibrium concentration spaces division of the $\mathrm{Fe}-\mathrm{Ag}-\mathrm{Te}-\mathrm{Ge}$ system in the parts $\mathrm{Ag}_{2} \mathrm{Te}-\mathrm{FeTe}_{2}-\mathrm{Fe}_{1.12} \mathrm{Te}$ and $\mathrm{Ag}_{8} \mathrm{GeTe}_{6}-\mathrm{GeTe}_{-} \mathrm{FeTe}_{2}-\mathrm{AgFeTe}_{2}-\mathrm{Ag}_{8} \mathrm{GeTe}_{6}$ into 3- and 4-phase regions were established. The phase regions position relative to the composition of $\mathrm{Ag}$ were used to express the overall potential reactions. Synthesis of the equilibrium set of phases in solid-state, including the $\mathrm{AgFeTe}_{2}, \mathrm{Ag}_{2} \mathrm{FeTe}_{2}$, and $\mathrm{Ag}_{2} \mathrm{FeGeTe}_{4}$ compounds, was conducted in the positive electrodes of ECCs. $\mathrm{Ag}^{+}$cations that shifted from the negative to positive electrode were serving as the nucleation centers for formation of stable compounds and catalysts for the synthesis of the equilibrium set of phases.

The linear relations of the EMF on $T$ of the ECCs were utilized for the calculations of the standard Gibbs energies, entropies, and enthalpies of formations of the ternary and quaternary compounds. Calculations of thermodynamic properties of the quaternary compound were performed in two independent potential forming processes. The similarity of $\Delta_{\mathrm{f}} G$ values in the two potential forming processes confirm the division of the concentration space of the $\mathrm{Fe}-\mathrm{Ag}-\mathrm{Te}-\mathrm{Ge}$ system and the composition of the phases in the positive electrodes within the ECCs were used to determine the thermodynamic 
quantities of the $\mathrm{AgFeTe}{ }_{2}, \mathrm{Ag}_{2} \mathrm{FeTe}_{2}$, and $\mathrm{Ag}_{2} \mathrm{FeGeTe}_{4}$ for the first time. Furthermore, the reproducibility of the determined $\Delta_{\mathrm{f}} G$ validate the literature Gibbs energy data for GeTe, $\mathrm{FeTe}_{2}$, and $\mathrm{Ag}_{8} \mathrm{GeTe}_{6}$ compounds.

The observed results in this work promote the development of thermodynamic data for the ternary and quaternary compounds, and enable modeling of the more complex phase diagrams of the Ag- $-\{\mathrm{Fe}, \mathrm{Co}, \mathrm{Ni}\}-\{\mathrm{Ge}, \mathrm{Sn}\}-\{\mathrm{S}, \mathrm{Se}, \mathrm{Te}\}$ systems. These thermodynamic data including thermal stability ranges of the multicomponent tellurides assist the discovery of new thermoelectric materials with high values of $Z T$ parameter, and other applications.

Author Contributions: Conceptualization, M.M., F.T. and O.R.; methodology, M.M., F.T., P.D. and O.R.; investigation, M.M. and P.D.; data curation, M.M., P.D., M.P. and N.Y.; writing-original draft preparation, M.M., F.T., P.D., M.P. and N.Y.; writing-review and editing, M.M., F.T., P.D., D.L., O.R. and L.H.; supervision, O.R., F.T., D.L. and L.H.; funding acquisition, O.R., P.D., F.T. and L.H. All authors have read and agreed to the published version of the manuscript.

Funding: This research was supported by the national projects of the Ministry of Education and Science of Ukraine: "Synthesis, physico-chemical and thermodynamic properties of nanosized and nanostructured materials for electrochemical systems" (No. 0120U102184). This work was partly supported by the Academy of Finland project (Decision number 311537), as part of the activities of the Johan Gadolin Process Chemistry Centre at Åbo Akademi University.

Institutional Review Board Statement: Not applicable.

Informed Consent Statement: Not applicable.

Data Availability Statement: Data is contained within the article.

Conflicts of Interest: The authors declare no conflict of interest.

\section{References}

1. Lee, K.H.; Kim, H.-S.; Kim, M.; Roh, J.W.; Lim, J.-H.; Kim, W.J.; Kim, S.-I.; Lee, W. Isovalent Sulfur Substitution to Induce a Simultaneous Increase in the Effective Mass and Weighted Mobility of a p-type Bi-Sb-Te Alloy: An Approach to Enhance the Thermoelectric Performance Over a Wide Temperature Range. Acta Mater. 2021, 205, 116578. [CrossRef]

2. Lv, S.; Qian, Z.; Hu, D.; Li, X.; He, W. A Comprehensive Review of Strategies and Approaches for Enhancing the Performance of Thermoelectric Module. Energies 2020, 13, 3142. [CrossRef]

3. Zoui, M.A.; Bentouba, S.; Stocholm, J.G.; Bourouis, M. A Review on Thermoelectric Generators: Progress and Applications. Energies 2020, 13, 3606. [CrossRef]

4. Ahluwalia, G.K. Data Storage Devices. In Applications of Chalcogenides: S, Se, and Te, 1st ed.; Ahluwalia, G.K., Ed.; Springer: Cham, Switzerland, 2017; pp. 323-370.

5. Chen, M.-M.; Xue, H.-G.; Guo, S.-P. Multinary metal chalcogenides with tetrahedral structures for second-order nonlinear optical, photocatalytic, and photovoltaic applications. Coord. Chem. Rev. 2018, 368, 115-133. [CrossRef]

6. Zeng, X.; Yan, C.; Ren, L.; Zhang, T.; Zhou, F.; Liang, X.; Wang, N.; Sun, R.; Xu, J.B.; Wong, C.P. Silver Telluride Nanowire Assembly for High-Performance Flexible Thermoelectric Film and Its Application in Self-Powered Temperature Sensor. Adv. Electron. Mater. 2019, 5, 1800612. [CrossRef]

7. Hull, S.; Berastegui, P.; Grippa, A. Ag ${ }^{+}$diffusion within the rock-salt structured superionic conductor $\mathrm{Ag}_{4} \mathrm{Sn}_{3} \mathrm{~S}_{8}$. J. Phys. Condens. Matter. 2005, 17, 1067-1084. [CrossRef]

8. Bailey, T.P.; Uher, C. Potential for superionic conductors in thermoelectric applications. Curr. Opin. Green Sustain. Chem. 2017, 4, 58-63. [CrossRef]

9. Shi, Y.; Sturm, C.; Kleinke, H. Chalcogenides as thermoelectric materials. J. Solid State Chem. 2019, 270, 273-279. [CrossRef]

10. Tesfaye, F.; Lindberg, D. Thermochemical properties of selected ternary phases in the Ag-Bi-S system. J. Mater. Sci. 2016, 51, 5750-5759. [CrossRef]

11. Swartzendruber, L.J. The Ag-Fe (Silver-Iron) system. Bull. Alloy Phase Diagr. 1984, 5, 560-564. [CrossRef]

12. Okamoto, H.; Tanner, L.E. The Fe-Te (Iron-Tellurium) system. Bull. Alloy Phase Diagr. 1990, 11, 371-376. [CrossRef]

13. Rodriguez, E.E.; Zavalij, P.; Hsieh, P.-Y.; Green, M.A. Iodine as an Oxidant in the Topotactic Deintercalation of Interstitial Iron in $\mathrm{Fe}_{1+x}$ Te. J. Am. Chem. Soc. 2010, 132, 10006-10008. [CrossRef]

14. Wernick, J.H.; Wolfe, R. Semiconducting “Compound” AgFeTe 2. J. Appl. Phys. 1961, 32, 749-774. [CrossRef]

15. Manca, P.; Massazza, F. Note on the Constitution of the Semiconducting “Compound" AgFeTe 2 . J. Appl. Phys. 1962, 33, 1608-1609. [CrossRef]

16. Manca, P.; Massazza, F. Reply to the Remark by E. L. Shtrum on the AgFeTe 2 Semiconductor "Compound." II. J. Appl. Phys. 1965, 36, 647-648. [CrossRef]

17. Deneke, K. A Remark on the Semiconducting Compound “AgFeTe 2 ". J. Appl. Phys. 1965, 36, 653. [CrossRef] 
18. Shtrum, E.L. AgFeTe 2 Semiconductor Compound: (A Remark on Papers by J. H. Wernick and R. Wolfe, and P. Manca and F. Massazza). J. Appl. Phys. 1964, 35, 252. [CrossRef]

19. Zaslavskii, A.I.; Zhukova, T.B. The structure of AgFeTe. J. Struct. Chem. 1965, 5, 222-224. [CrossRef]

20. Aliev, S.A.; Gasanov, Z.S.; Mamedova, S.O. The phenomenon of a hysteresis in $\mathrm{AgFeTe}_{2}$ in phase transition region. Fizika 2004, 10, 25-29.

21. Aliev, M.I.; Gasanov, Z.S.; Guseinov, F.Z. Physical properties of iron silver telluride $\left(\mathrm{AgFeTe}_{2}\right)$ in the phase transition region. Izv. Akad. Nauk SSSR Neorg. Mater. 1974, 10, 1897-1898.

22. Amulevicius, A.; Baltrunas, D. Moessbauer parameters and some physical properties of silver iron telluride $\left(\mathrm{AgFeTe}_{2}\right) \mathrm{in}_{\mathrm{f}} \mathrm{the}$ phase transition region. Liet. Fiz. Rink. 1978, 18, 243-250.

23. Aliev, M.I.; Guseinov, F.Z.; Gasanov, Z.S.; Dzhafarov, Z.A. Thermal properties of AgMeX ${ }_{2}$ compounds (Me-iron, nickel, Xselenium, tellurium). Dokl. Akad. Nauk Azerbaidzhanskoi SSR 1978, 34, 15-19.

24. Merwin, H.E.; Lombard, R.H. The system Cu-Fe-S. Econ. Geol. 1937, 32, 203-284. [CrossRef]

25. Blachnik, R.; Stöter, U. The phase diagram AgI-ZnI 2 . Thermochim. Acta 1989, 145, 93-99. [CrossRef]

26. Karapetyants, M.K. The Chemical Thermodynamics; Goskhimizdat: Moscow, Russia, 1953. (In Russian)

27. O'Connell, J.P.; Haile, J.M. Thermodynamics: Fundamentals for Applications; Cambridge University Press: Cambridge, UK, 2005; pp. 310-365.

28. Moroz, M.; Tesfaye, F.; Demchenko, P.; Prokhorenko, M.; Kogut, Y.; Pereviznyk, O.; Prokhorenko, S.; Reshetnyak, O. Solid-state electrochemical synthesis and thermodynamic properties of selected compounds in the Ag-Fe-Pb-Se system. Solid State Sci. 2020, 107, 106344. [CrossRef]

29. Voronin, M.V.; Osadchii, E.G.; Brichkina, E.A. Thermochemical properties of silver tellurides including empressite (AgTe) and phase diagrams for Ag-Te and Ag-Te-O. Phys. Chem. Miner. 2017, 44, 639-653. [CrossRef]

30. Moroz, M.V.; Demchenko, P.Y.; Prokhorenko, M.V.; Reshetnyak, O.V. Thermodynamic Properties of Saturated Solid Solutions of the Phases $\mathrm{Ag}_{2} \mathrm{PbGeS}_{4}, \mathrm{Ag}_{0.5} \mathrm{~Pb}_{1.75} \mathrm{GeS}_{4}$ and $\mathrm{Ag}_{6.72} \mathrm{~Pb}_{0.16} \mathrm{Ge}_{0.84} \mathrm{~S}_{5.20}$ of the Ag-Pb-Ge-S System Determined by EMF Method. J. Phase Equilibria Diffus. 2017, 38, 426-433. [CrossRef]

31. Abrikosov, N.K.; Stasova, M.M. Solid solutions based on bismuth and antimony tellurides and bismuth selenides. Izv. Akad. Nauk SSSR Neorg. Mater. 1985, 21, 2011-2015.

32. Shelimova, L.E.; Karpinsky, O.G.; Kretova, M.A.; Avilov, E.S. Phase equilibria in the Ge-Bi-Te ternary system at 570-770 K temperature range. J. Alloys Compd. 1996, 243, 194-201. [CrossRef]

33. Moroz, M.V.; Prokhorenko, M.V. Phase relations in PbSe-PbTe alloys of the Ag-Pb-Se-Te system studied by EMF measurements. Inorg. Mater. 2015, 51, 302-306. [CrossRef]

34. Moroz, M.V.; Prokhorenko, M.V. Determination of thermodynamic properties of saturated solid solutions of the Ag-Ge-Se system using EMF technique. Russ. J. Electrochem. 2015, 51, 697-702. [CrossRef]

35. Prokhorenko, M.V.; Moroz, M.V.; Demchenko, P.Y. Measuring the thermodynamic properties of saturated solid solutions in the $\mathrm{Ag}_{2} \mathrm{Te}-\mathrm{Bi}_{-} \mathrm{Bi}_{2} \mathrm{Te}_{3}$ system by the electromotive force method. Russ. J. Phys. Chem. A 2015, 89, 1330-1334. [CrossRef]

36. Quintero, M.; Barreto, A.; Grima, P.; Tovar, R.; Quintero, E.; Porras, G.S.; Ruiz, J.; Woolley, J.C.; Lamarche, G.; Lamarche, A.-M. Crystallographic properties of $\mathrm{I}_{2}-\mathrm{Fe}-\mathrm{IV}-\mathrm{VI}_{4}$ magnetic semiconductor compounds. Mater. Res. Bull. 1999, 34, $2263-2270$. [CrossRef]

37. Kroupa, A. Modelling of phase diagrams and thermodynamic properties using Calphad method—Development of thermodynamic databases. Comput. Mater. Sci. 2013, 66, 3-13. [CrossRef]

38. Jung, I.-H.; Van Ende, M.-A. Computational Thermodynamic Calculations: FactSage from CALPHAD Thermodynamic Database to Virtual Process Simulation. Metall. Mater. Trans. B 2020, 51, 1851-1874. [CrossRef]

39. Diffractom. Stoe WinXPOW Version 303; Stoe Cie GmbH: Darmstadt, Germany, 2010.

40. Kraus, W.; Nolze, G. POWDER CELL-Program Represent. Manip. Cryst. Struct. Calcul. Result. X-Ray Powder Patterns 1996, 29, 301-303.

41. Villars, P.; Cenzual, K. Pearson's Crystal Data: Crystal Structure Database for Inorganic Compounds, Release 2014/15; ASM International: Materials Park, OH, USA, 2014.

42. Robinel, E.; Carette, B.; Ribes, M. Silver sulfide based glasses (I): Glass forming regions, structure and ionic conduction of glasses in $\mathrm{GeS}_{2}-\mathrm{Ag}_{2} \mathrm{~S}$ and $\mathrm{GeS}_{2}-\mathrm{Ag}_{2} \mathrm{~S}-\mathrm{AgI}$ systems. J. Non-Cryst. Solids 1983, 57, 49-58. [CrossRef]

43. Moroz, M.V.; Demchenko, P.Y.; Mykolaychuk, O.G.; Akselrud, L.G.; Gladyshevskii, R.E. Synthesis and electrical conductivity of crystalline and glassy alloys in the $\mathrm{Ag}_{3} \mathrm{GeS}_{3} \mathrm{Br}_{-} \mathrm{GeS}_{2}$ system. Inorg. Mater. 2013, 49, 867-871. [CrossRef]

44. Moroz, M.; Tesfaye, F.; Demchenko, P.; Prokhorenko, M.; Lindberg, D.; Reshetnyak, O.; Hupa, L. Determination of the thermodynamic properties of the $\mathrm{Ag}_{2} \mathrm{CdSn}_{3} \mathrm{~S}_{8}$ and $\mathrm{Ag}_{2} \mathrm{CdSnS}_{4}$ phases in the Ag-Cd-Sn-S system by the solid-state electrochemical cell method. J. Chem. Thermodyn. 2018, 118, 255-262. [CrossRef]

45. Santoso, I.; Taskinen, P. Thermodynamic properties of Ag-Au-Pd alloys measured by a solid-state EMF method. J. Mater. Sci. 2018, 58, 9232-9242. [CrossRef]

46. Jendrzejczyk-Handzlik, D.; Fitzner, K. Thermodynamic stability of copper gallates determined from the E.M.F. method. J. Solid State Chem. 2015, 232, 207-212. [CrossRef] 
47. Babanly, M.B.; Mashadiyeva, L.F.; Babanly, D.M.; Imamaliyeva, S.Z.; Tagiev, D.B.; Yusibov, Y.A. Some Issues of Complex Studies of Phase Equilibria and Thermodynamic Properties in Ternary Chalcogenide Systems Involving Emf Measurements (Review). Russ. J. Inorg. Chem. 2019, 64, 1649-1671. [CrossRef]

48. Imamaliyeva, S.Z.; Musayeva, S.S.; Babanly, D.M.; Jafarov, Y.I.; Taghiyev, D.B.; Babanly, M.B. Determination of the thermodynamic functions of bismuth chalcoiodides by EMF method with morpholinium formate as electrolyte. Thermochim. Acta 2019, 679, 178319. [CrossRef]

49. Mukherjee, S.; Dash, S. Thermodynamic study of $\mathrm{NaLaF}_{4}$ in $\mathrm{NaF}_{-} \mathrm{LaF}_{3}$ system using solid state electrochemical cell method. J. Solid State Chem. 2019, 277, 61-67. [CrossRef]

50. Moroz, M.V.; Demchenko, P.Y.; Prokhorenko, S.V.; Moroz, V.M. Physical properties of glasses in the $\mathrm{Ag}_{2} \mathrm{GeS}_{3}-\mathrm{AgBr}_{\mathrm{B}}$ system. Phys. Solid State. 2013, 55, 1613-1618. [CrossRef]

51. Moroz, M.V.; Prokhorenko, M.V.; Prokhorenko, S.V. Determination of thermodynamic properties of Ag3SBr superionic phase using EMF technique. Russ. J. Electrochem. 2015, 51, 886-889. [CrossRef]

52. Moroz, M.V.; Prokhorenko, M.V.; Demchenko, P.Y.; Reshetnyak, O.V. Thermodynamic properties of saturated solid solutions of $\mathrm{Ag}_{7} \mathrm{SnSe}_{5} \mathrm{Br}$ and $\mathrm{Ag}_{8} \mathrm{SnSe}_{6}$ compounds in the Ag-Sn-Se-Br system measured by the EMF method. J. Chem. Thermodyn. 2017, 106, 228-231. [CrossRef]

53. Aspiala, M.; Tesfaye, F.; Taskinen, P. Electrochemical study on the Ag-Sb system by advanced experimental method. Electrochim. Acta 2015, 173, 649-655. [CrossRef]

54. Moroz, M.V.; Prokhorenko, M.V.; Rudyk, B.P. Thermodynamic properties of phases of the Ag-Ge-Te system. Russ. J. Electrochem. 2014, 50, 1177-1181. [CrossRef]

55. Moroz, M.V.; Prokhorenko, M.V. Thermodynamic properties of the intermediate phases of the Ag-Sb-Se system. Russ. J. Phys. Chem. A 2014, 88, 742-746. [CrossRef]

56. Moroz, M.V.; Prokhorenko, M.V.; Reshetnyak, O.V.; Demchenko, P.Y. Electrochemical determination of thermodynamic properties of saturated solid solutions of $\mathrm{Hg}_{2} \mathrm{GeSe}_{3}, \mathrm{Hg}_{2} \mathrm{GeSe}_{4}, \mathrm{Ag}_{2} \mathrm{Hg}_{3} \mathrm{GeSe}_{6}$, and $\mathrm{Ag}_{1.4} \mathrm{Hg}_{1.3} \mathrm{GeSe}_{6}$ compounds in the $\mathrm{Ag}-\mathrm{Hg}-\mathrm{Ge}-\mathrm{Se}$ system. J. Solid State Electrochem. 2017, 21, 833-837. [CrossRef]

57. Mashadieva, L.F.; Kevser, J.O.; Aliev, I.I.; Yusibov, Y.A.; Tagiyev, D.B.; Aliev, Z.S.; Babanly, M.B. Phase equilibria in the Ag 2 Te$\mathrm{SnTe}_{-} \mathrm{Sb}_{2} \mathrm{Te}_{3}$ system and thermodynamic properties of the $(2 \mathrm{SnTe})_{1-\mathrm{x}}(\mathrm{AgSbTe})_{\mathrm{x}}$ solid solution. J. Phase Equilibria Diffus. 2017, 38, 603-614. [CrossRef]

58. Tengner, S. Über Diselenide und Ditelluride von Eisen, Kobalt und Nickel. Z. Für Anorg. Allg. Chem. 1938, $239,126-132$. [CrossRef]

59. Goryunova, N.A. The Chemistry of Diamond-Like Semiconductors; Chapman and Hall: London, UK, 1965.

60. Babanly, M.; Yusibov, Y.; Babanly, N. The EMF method with solid-state electrolyte in the thermodynamic investigation of ternary copper and silver chalcogenides. In Electromotive Force and Measurement in Several Systems; Kara, S., Ed.; InTech: London, UK, 2011; pp. 57-78.

61. Gordon, A.J.; Ford, R.A. The Chemist's Companion: A Handbook of Practical Data, Techniques, and References; Wiley: New York, NY, USA, 1972.

62. Morachevskii, A.G.; Voronin, G.F.; Geyderikh, V.A.; Kutsenok, I.B. Electrochemical Research Methods in the Thermodynamics of Metallic Systems; Akademkniga: Moscow, Russia, 2003. (In Russian)

63. Gravetter, F.J.; Wallnau, L.B. Statistics for the Behavioral Sciences, 10th ed.; Cengage Learning: Victoria, Australia; Belmont, CA, USA, 2017; ISBN 978-1-305-50491-2.

64. Babanly, N.B.; Orujlu, E.N.; Imamaliyeva, S.Z.; Yusibov, Y.A.; Babanly, M.B. Thermodynamic investigation of silver-thallium tellurides by EMF method with solid electrolyte $\mathrm{Ag}_{4} \mathrm{RbI}_{5}$. J. Chem. Thermodyn. 2019, 128, 78-86. [CrossRef]

65. Voronin, M.V.; Osadchii, E.G. Thermodynamic properties of silver and bismuth sulfosalt minerals, pavonite $\left(\mathrm{AgBi}_{3} \mathrm{~S}_{5}\right)$ and matildite $\left(\mathrm{AgBiS}_{2}\right)$ and implications for ore deposits. Econ. Geol. 2013, 108, 1203-1210. [CrossRef]

66. Barin, I. Thermochemical Data of Pure Substance; VCH: Weinheim, Germany, 1995.

67. Ferhat, A.; Ollitrault-Fichet, R.; Rivet, J. Description du système ternaire Ag-Ge-Te. J. Alloys Compd. 1991, 177, 337-355. [CrossRef] 